\title{
YIELD AND QUALITY CHARACTERISTICS OF SOME ALFALFA (Medicago sativa L.) VARIETIES GROWN IN THE EASTERN TURKEY
}

\author{
Nizamettin TURAN ${ }^{1 *}$, A. Esen CELEN ${ }^{2}$, Mehmet Arif OZYAZICI ${ }^{1}$
}

${ }^{1}$ Siirt University, Faculty of Agriculture, Department of Field Crops, Siirt, TURKEY

${ }^{2}$ Ege University, Faculty of Agriculture, Department of Field Crops, Izmir, TURKEY

* Corresponding author: nturan49@siirt.edu.tr

Received: 22.05.2017

\begin{abstract}
This research was carried out between 2009 and 2011 to determine the herbage yield and some agricultural and quality characteristics of alfalfa varieties under the ecological conditions of Eastern Anatolia, Gurpinar, Van Turkey. Six alfalfa varieties were grown, including domestic Kayseri, Bilensoy-80 and Van Native (ecotype) in addition to varieties Planet, Plato and CW-3567 of foreign origin. It was found that means of alfalfa varieties ranged from 77.9 to $82.3 \mathrm{~cm}$ for plant height; from 29.9 to 33.4 for number of main stems per plant; from 8.32 to $9.38 \%$ for crude ash and from 16.55 to $17.55 \%$ for protein content. The differences among the varieties for certain traits were not statistically significant. However, Van Native $\left(43575 \mathrm{~kg} \mathrm{ha}^{-1}\right)$ and CW$3567\left(43242 \mathrm{~kg} \mathrm{ha}^{-1}\right)$ gave high fresh herbage yields whereas CW-3567 (16201 kg ha-1), Van Native (15519 kg $\mathrm{ha}^{-1}$ ) and Kayseri (15194 $\left.\mathrm{kg} \mathrm{ha}^{-1}\right)$ gave high hay yields. Beside, CW-3567 (2827 kg ha-1) was the best variety for crude protein yield. Based on the results of the study, it could be said that cultivar $\mathrm{CW}-3567$ could be recommended to be grown under the ecological conditions of Eastern Anatolia.
\end{abstract}

Keywords: Alfalfa, Medicago sativa L., variety, yield

\section{INTRODUCTION}

Alfalfa (Medicago sativa L.), a native plant of the Near East and Central Asia, is widely grown forage crop in the world. It has higher feed value than almost all forage plants cultivated with high protein yield per unit area (Acikgoz, 2001). It has varieties grown under extreme climatic conditions, such as the cold zones of Alaska and Siberia, where the winter colds reach to -50 ${ }^{\circ} \mathrm{C}$, and California's Death Valley, where the summer temperatures rise to $60{ }^{\circ} \mathrm{C}$. Also, it has varieties having the ability to grow at different altitudes from sea level to $3000 \mathrm{~m}$.

The performance yield and some quality characteristics of different alfalfa varieties and lines were studied at different climatic and soil conditions in Turkey such as Samsun, Erzurum, Aegean Region, Southeastern Anatolia Region, Kirsehir and İsparta in Turkey (Aydin et al., 1994; Seker, 2003; Sengul et al., 2003; Demiroglu et al., 2008; Kir and Soya, 2008; Demiroglu and Avcioglu, 2010; Kavut et al., 2014; Saruhan and Kusvuran, 2011; Inal, 2015; Yilmaz and Albayrak, 2016) and the superior genotypes were proposed to the farmers. Although the area of cultivation has increased greatly in recent years, the production of alfalfa has not reached to the desired level. In Turkey a total of 2.609.878 hectares are used for forage crops and only 652.259 hectares of this area are devoted to alfalfa (Anonymous, 2017).

In Van, a province located in the eastern Turkey, majority of people in rural areas occupy in agriculture and animal husbandry. Livestock enterprises' roughage requirements are generally met by natural meadow and pasture areas. Because of heavy and extreme weather temperatures are prevalent in the region, the green fodder period is quite short and therefore some difficulties are encountered in providing roughage. Therefore it is important to increase forage cultivation to provide roughage need in the region. So the adaptation of highyielding alfalfa varieties and to increase the cultivation areas in Van province would be an important impact in increasing the quantity and quality of animal products to decrease roughage deficiency.

Rapid developments in plant breeding have given farmers an opportunity to grow new high yielding alfalfa varieties. In order to realize this aim adaptation studies, should be conducted in the region. Strbanovic et al. (2017) found that 15 alfalfa genotypes originating from America 
and Europe differed in dry matter yield. Considering these studies done, it could be said that ecological factors such as climate and soil play an important role on the performance of alfalfa varieties. Although alfalfa has a wide adaptability, the yield and developmental characteristics of many alfalfa varieties vary greatly from region to region. Therefore it is important to determine genotypes suitable to specific ecologies. The purpose of this preliminary research was to determine alfalfa cultivars with high yield, high quality and high adaptation capacity to the ecological conditions of Eastern Anatolia.

\section{MATERIALS AND METHODS}

A field trial was conducted at Gurpinar, Van, Turkey (latitude $37^{\circ} 43^{\prime} \mathrm{N}$, longitude $42^{\circ} 40^{\prime} \mathrm{E}$, elevation
$1730 \mathrm{~m}$ ) during the 2009, 2010 and 2011 growing seasons. The soil of the research field was loamy in texture with $\mathrm{pH} 7.8,4.70 \% \mathrm{CaCO} 3$, and $2.58 \%$ organic matter. Available phosphor us was $69 \mathrm{ha}^{-1}$ and available potassium was $2430 \mathrm{~kg} \mathrm{ha}^{-1}$. There was no salinity problem.

The climatic data for the research area are given in Table 1 . The long years average temperature in the region is $9.3{ }^{\circ} \mathrm{C}$, the average temperature values for 2009,2010 and 2011 were $9.5,11.8$ and $9.5^{\circ} \mathrm{C}$, respectively. The total precipitation during 2009, 2010 and 2011 was 484.5, 379.6 and $517.1 \mathrm{~mm}$, respectively. In the establishment year and the last year of the study the precipitation was higher than the long years' average (Table 1).

Table 1. Temperature, precipitation and relative humidity of the research area*

\begin{tabular}{|c|c|c|c|c|c|c|c|c|c|c|c|c|}
\hline & \multicolumn{4}{|c|}{ Temperature $\left({ }^{0} \mathrm{C}\right)$} & \multicolumn{4}{|c|}{ Precipitation (mm) } & \multicolumn{4}{|c|}{ Relative Humidity (\%) } \\
\hline Months & LYA $* *$ & 2009 & 2010 & 2011 & AMY & 2009 & 2010 & 2011 & AMY & 2009 & 2010 & 2011 \\
\hline January & -3.3 & -3.6 & 1.2 & -1.3 & 33.1 & 42.9 & 51.6 & 14.2 & 68.7 & 67.9 & 71.6 & 66.5 \\
\hline February & -2.5 & 0.4 & 1.9 & -0.5 & 33.8 & 49.2 & 71.1 & 26.6 & 69.2 & 68.8 & 72.8 & 67.0 \\
\hline March & 1.8 & 2.2 & 6.5 & 2.4 & 45.9 & 74.8 & 38.3 & 30.7 & 67.4 & 63.9 & 61.5 & 62.5 \\
\hline April & 7.8 & 6.4 & 8.6 & 8.7 & 56.5 & 47.1 & 46.3 & 133.7 & 61.6 & 56.9 & 63.2 & 60.4 \\
\hline May & 12.9 & 12.9 & 13.3 & 12.6 & 46.9 & 31.9 & 69.8 & 62.8 & 56.6 & 46.5 & 62.3 & 62.3 \\
\hline June & 18.0 & 17.5 & 19.7 & 18.7 & 19.2 & 27.1 & 41.0 & 28.1 & 49.3 & 47.8 & 46.2 & 50.2 \\
\hline July & 22.1 & 20.9 & 23.7 & 22.8 & 5.8 & 21.2 & 0.0 & 11.0 & 43.9 & 44.0 & 36.7 & 40.7 \\
\hline August & 22.0 & 20.4 & 23.3 & 22.7 & 6.2 & 2.5 & 1.0 & 0.2 & 41.9 & 37.3 & 34.5 & 38.8 \\
\hline September & 17.7 & 15.8 & 20.4 & 17.7 & 17.4 & 46.0 & 3.8 & 53.0 & 43.8 & 49.8 & 40.0 & 44.1 \\
\hline October & 11.3 & 12.0 & 13.6 & 10.0 & 47.6 & 15.9 & 45.8 & 125.9 & 58.5 & 55.1 & 56.2 & 61.4 \\
\hline November & 4.7 & 5.7 & 6.0 & 1.0 & 48.1 & 91.1 & 2.2 & 18.8 & 65.9 & 66.6 & 55.6 & 66.1 \\
\hline December & -0.5 & 3.0 & 3.1 & -0.6 & 38.1 & 34.8 & 8.7 & 12.1 & 68.6 & 73.0 & 59.3 & 70.5 \\
\hline Total & & & & & 398.6 & 484.5 & 379.6 & 517.1 & & & & \\
\hline Average & 9.3 & 9.5 & 11.8 & 9.5 & & & & & 58.0 & 56.5 & 55.0 & 57.5 \\
\hline
\end{tabular}

The genetic material of the study was obtained from Agricultural Research Institutes and private seed companies. Six alfalfa varieties were studied. Kayseri, Bilensoy-80 and Van Native (ecotype) were domestic varieties whereas Planet, Plato and CW-3567 were foreign ones. The varieties were tall with vertical development characters. But they were all resistant to lodging.

The trial was arranged in a Randomized Complete Block Design with three replications. The plot size was $2.40 \mathrm{~m} \times 5 \mathrm{~m}=12.0 \mathrm{~m}^{2}$, which consisted of 8 rows spaced at $30 \mathrm{~cm}$ apart (Altin and Gokkus, 1988). Sowing rate was $30 \mathrm{~kg} \mathrm{ha}^{-1}$. The planting was done on April 26, 2009 with a hand marker. During the planting, diammonium phosphate (DAP) fertilizer was applied according to the results of soil analysis as $27 \mathrm{~kg} \mathrm{~N}$ and $69 \mathrm{~kg} \mathrm{ha}^{-1} \mathrm{P}_{2} \mathrm{O}_{5}$. No evaluation was made in the establishment year of the study. Normal harvest and maintenance procedures were done during the experiment and required measurements and observed were performed in 2010 and 2011.

The harvesting was done by leaving a height of $5 \mathrm{~cm}$ in the period of $10 \%$ flowering, leaving a row edge effect from the sides of the plots and $50 \mathrm{~cm}$ from the beginning of the each plot. The plot yields were converted to hectare. For hay yield plant samples were dried at $65{ }^{\circ} \mathrm{C}$ for $48 \mathrm{~h}$ until constant weight. Nitrogen and crude ash contents were determined by using method described by Kacar and Inal (2008) and crude protein content ( $\mathrm{N}$ x 6.25 ) and crude protein yield were calculated. In each year three harvests were done. In the study plant height $(\mathrm{cm})$, number of main stems per plant, fresh herbage yield $(\mathrm{kg}$ $\left.\mathrm{ha}^{-1}\right)$, hay yield $\left(\mathrm{kg} \mathrm{ha}^{-1}\right)$, crude ash content $(\%)$, crude protein content $(\%)$ and crude protein yield $\left(\mathrm{kg} \mathrm{ha}^{-1}\right)$ were obtained and statistically analyzed.

Data were subjected to the standard analysis of variance. Means were compared by the LSD multiple comparison test (Steel and Torrie, 1980).

\section{RESULTS AND DISCUSSION}

\section{Plant height}

Means of alfalfa varieties are given in Table 2. It can be seen in Table 2 that, although there were no statistically significant differences among the varieties for plant height, the year $\mathrm{x}$ variety interaction was statistically significant $(\mathrm{P}<0.01)$. The highest plant height was 
obtained from Plato variety with $88.0 \mathrm{~cm}$ in 2010, while the highest plant height was taken from planet variety with $82.4 \mathrm{~cm}$ in 2011. The lowest plant heights for 2010 and 2011 were obtained for the Bilensoy-80 $(74.7 \mathrm{~cm})$ and Plato $(76.6 \mathrm{~cm})$, respectively. All other varieties except Plato showed low plant height in the first year, and a slight increase in average plant height was observed in the second year. Although similar air temperatures prevailed the growing period in 2010 and 2011, high rainfall of $133.7 \mathrm{~mm}$ in April especially, might have caused the second year plants to be taller.

Table 2. The means of plant height $(\mathrm{cm})$ and number of main stems (number/plant) of alfalfa varieties

\begin{tabular}{|c|c|c|c|c|c|c|}
\hline \multirow{2}{*}{ Varieties } & \multicolumn{3}{|c|}{ Plant height } & \multicolumn{3}{|c|}{ Number of main stems } \\
\hline & 2010 & 2011 & Average & 2010 & 2011 & Average \\
\hline CW-3567 & $77.9 \mathrm{bcd}$ & 80.9 bc & 79.4 & 29.33 & 33.88 & 31.6 \\
\hline Plato & $88.0 \mathrm{a}$ & $76.6 \mathrm{~cd}$ & 82.3 & 36.78 & 30.00 & 33.4 \\
\hline Planet & $77.4 \mathrm{~cd}$ & $82.4 \mathrm{~b}$ & 79.9 & 30.66 & 32.00 & 31.3 \\
\hline Van Native & $77.9 \mathrm{bcd}$ & 80.9 bc & 79.4 & 29.33 & 30.77 & 30.0 \\
\hline Kayseri & $79.6 \mathrm{bcd}$ & $80.1 \mathrm{bc}$ & 79.8 & 31.55 & 28.33 & 29.9 \\
\hline Bilensoy-80 & $74.7 \mathrm{~d}$ & $81.2 \mathrm{bc}$ & 77.9 & 33.56 & 30.00 & 31.8 \\
\hline Average & 79.2 & 80.4 & & $31.90 \mathrm{a}$ & $30.80 \mathrm{~b}$ & \\
\hline & $\mathrm{LSD}_{\text {yearx variety }}=4.906^{* *}$ & & & $\mathrm{LSD}_{\text {year }}=0.610^{* *}$ & & \\
\hline
\end{tabular}

The average plant length of the varieties ranged from $77.9-82.3 \mathrm{~cm}$. Our results were in agreement with the results of Seker (2003) who studied similar cultivars in Erzurum, and the results of many researchers (Demiroglu et al., 2008; Saruhan and Kusvuran, 2011; Kavut et al., 2014; Inal, 2015).

\section{Number of Main Stems}

The average number of main stems is also presented in Table 2 . There were no statistically significant differences among the varieties and the number of main stems per plant varied between 29.9 and 33.4 for the varieties. The values obtained for the number of main stems were higher than some earlier results (Seker, 2003; Demiroglu et al., 2008; Kavut et al., 2014 and Inal, 2015).

In the study, statistically significant differences were found between the years $(\mathrm{P}<0.01)$, and the number of main stems measured were higher in the first year (Table 2).

\section{Fresh Herbage Yield}

Fresh herbage yields are shown in Table 3. Significant differences were found among the varieties $(\mathrm{P}<0.01)$ and for the year $\mathrm{x}$ variety interaction $(\mathrm{P}<0.05)$. First year the highest fresh herbage yields were obtained from $\mathrm{CW}$ 3567, Plato and Van Native while Kayseri, CW-3567 and Van Native gave the highest yields in the second year (Table 3). In a study carried out with CW-3567, Planet and Kayseri varieties under Erzurum ecological conditions, fresh herbage yields of Kayseri and CW-3567 were reported as 58014 and $55423 \mathrm{~kg} \mathrm{ha}^{-1}$, respectively (Seker, 2003) but there was no statistically significant difference between yields.

Table 3. The means of fresh herbage and hay yields of alfalfa varieties $\left(\mathrm{kg} \mathrm{ha}^{-1}\right)$

\begin{tabular}{lcccccc}
\hline \multirow{2}{*}{ Varieties } & \multicolumn{3}{c}{ Fresh herbage yield } & \multicolumn{2}{c}{ Hay yield } \\
\cline { 2 - 6 } & $\mathbf{2 0 1 0}$ & $\mathbf{2 0 1 1}$ & Average & $\mathbf{2 0 1 0}$ & $\mathbf{2 0 1 1}$ & Average \\
\hline CW-3567 & $42167 \mathrm{a}$ & $44317 \mathrm{a}$ & $43242 \mathrm{~A}$ & 14817 & 17585 & $16201 \mathrm{~A}$ \\
Plato & $41250 \mathrm{a}$ & $37017 \mathrm{~b}$ & $39133 \mathrm{~B}$ & 14693 & 14755 & $14724 \mathrm{~B}$ \\
Planet & $27010 \mathrm{~d}$ & $31433 \mathrm{c}$ & $29222 \mathrm{D}$ & 6898 & 8841 & $7869 \mathrm{D}$ \\
Van Native & $42167 \mathrm{a}$ & $44983 \mathrm{a}$ & $43575 \mathrm{~A}$ & 14999 & 16040 & $15519 \mathrm{AB}$ \\
Kayseri & $36983 \mathrm{~b}$ & $42367 \mathrm{a}$ & $39675 \mathrm{~B}$ & 13327 & 17059 & $15194 \mathrm{AB}$ \\
Bilensoy-80 & $32217 \mathrm{c}$ & $33533 \mathrm{bc}$ & $32875 \mathrm{C}$ & 8567 & 10268 & $9417 \mathrm{C}$ \\
Average & 36966 & 3894.2 & 37954 & $12217 \mathrm{~b}$ & $14091 \mathrm{a}$ & 13154 \\
& LSD $_{\text {variety }}=2784^{* *}$, LSD $_{\text {yearxvariety }}=3938^{*}$ & LSD $_{\text {year }}=1233^{* *}$, LSD $_{\text {variety }}=1282^{* *}$ \\
\hline
\end{tabular}

The difference between the averages indicated by the same letter in the same group is not statistically significant. *: Significant difference at $\mathrm{P}<0.05$ level, **: Significant difference at $\mathrm{P}<0.01$ level, CV: Variation coefficient, LSD: Least Significant Difference

Kayseri used as a control in the study was in the second group as for fresh herbage yield with $39675 \mathrm{~kg} \mathrm{ha}$ ${ }^{1}$. Fresh herbage yields obtained from our study were found lower than the results of Cevheri and Avcioglu (1998), Eginlioglu et al. (1996), but higher than the results of Sengul and Tahtacioglu (1996). 


\section{Hay yield}

There were highly significant differences among means of the varieties (Table 3 ). Hay yields in the second year were higher than those of the first year. This could be attributed to rainfall in the second year, especially the rainfall obtained in April, was higher than the first year. Similarly, fresh herbage yield was higher in the second year.

The highest hay yield (16201 $\left.\mathrm{kg} \mathrm{ha}^{-1}\right)$ was obtained from variety $\mathrm{CW}-3567$, while the lowest hay yield was taken from Planet $\left(7869 \mathrm{~kg} \mathrm{ha}^{-1}\right)$. Considering the yields of two-year, total hay yields seemed to be in parallel with the fresh herbage yields (Table 3 ). In a study done by Seker (2003) highest hay yield (13335 kg ha-1) was reported for Kayseri. Variety CW-3567 had $12301 \mathrm{~kg} \mathrm{ha}^{-1}$ yield. But difference between yields was not statistically significant. These results were partly similar to our findings.

In a study carried out in the Southeastern Anatolian Region, Saruhan and Kusvuran (2011), stated that the local genotypes had high yields statistically similar to the Elci variety cultivated widely in Turkey and Bilensoy gave lower hay yields. Our results were similar to their results. In another study conducted at Bornova and
Odemis (Demiroglu et al., 2008), including Tru-test, Bacana, FG8R612, P-5683 and Ambassador alfalfa varieties, average yields for year and location were reported to vary between $18920-24740 \mathrm{~kg} \mathrm{ha}^{-1}$. Hay yields obtained from our research were found to be lower than the results of Bilensoy (1985), Sengul and Tahtacioglu (1996) and Kavut et al. (2014), but higher than the results of Cevheri and Avcioglu (1998) and Inal (2015).

\section{Crude Ash Content}

The mean crude ash contents are given in Table 4. There were no statistically significant differences in terms of crude ash among the varieties and crude ash contents ranged between 8.32 and $9.38 \%$. Gungor et al. (2008) and Kavut and Avcioglu (2015) found 7.48-11.27\% and 8.82$9.43 \%$ crude ash contents, respectively. Our results were similar to their results. Manga (1978), Acar (2002) and Geleti et al. (2014) found 12.85-15.56\%, 11.37-12.02\% and 10.03-10.69\% crude ash contents in their studies, respectively and their means were higher than our results. Tongel and Ayan (2010) reported that the crude ash contents ranged between 7.50-8.45 \% in the second harvest. Acikgoz (2001) stated that the variation of crude ash content of the varieties depend on soil and climatical factors.

Table 4. The means of crude ash content (\%), crude protein content (\%) and crude protein yield $\left(\mathrm{kg} \mathrm{ha}^{-1}\right)$ of alfalfa varieties

\begin{tabular}{|c|c|c|c|c|c|c|c|c|c|}
\hline \multirow{2}{*}{ Varieties } & \multicolumn{3}{|c|}{ Crude ash ratio } & \multicolumn{3}{|c|}{ Crude protein ratio } & \multicolumn{3}{|c|}{ Crude protein yield } \\
\hline & 2010 & 2011 & Average & 2010 & 2011 & Average & 2010 & 2011 & Average \\
\hline CW-3567 & 8.98 & 9.05 & 9.02 & 18.07 & 16.87 & 17.47 & 2677 & 2976 & $2827 \mathrm{a}$ \\
\hline Plato & 8.18 & 9.09 & 8.63 & 16.85 & 16.89 & 16.87 & 2476 & 2482 & $2479 \mathrm{~b}$ \\
\hline Planet & 9.73 & 8.66 & 9.19 & 17.67 & 16.69 & 17.17 & 1219 & 1478 & $1348 \mathrm{~d}$ \\
\hline Van Native & 8.98 & 9.05 & 9.02 & 16.33 & 16.87 & 16.60 & 2449 & 2705 & $2577 \mathrm{~b}$ \\
\hline Kayseri & 10.14 & 8.62 & 9.38 & 16.43 & 16.68 & 16.55 & 2190 & 2840 & $2515 \mathrm{~b}$ \\
\hline Bilensoy-80 & 7.29 & 9.35 & 8.32 & 16.84 & 18.26 & 17.55 & 1443 & 1871 & $1657 \mathrm{c}$ \\
\hline Average & 8.88 & 8.97 & & 17.03 & 17.04 & & $2076 \mathrm{~b}$ & $2392 \mathrm{a}$ & \\
\hline \multicolumn{4}{|c|}{$\mathrm{CV}(\%)=10.87$} & \multicolumn{3}{|c|}{$\mathrm{CV}(\%)=5.82$} & \multicolumn{3}{|c|}{$\begin{array}{l}\mathrm{CV}(\%)=9.17 \\
\mathrm{LSD}_{\text {year }}=224.7^{*}, \mathrm{LSD}_{\text {varietyt }}=246.6^{* *}\end{array}$} \\
\hline
\end{tabular}

The difference between the averages indicated by the same letter in the same group is not statistically significant. $*:$ Significant difference at $\mathrm{P}<0.05$ level, **: Significant difference at $\mathrm{P}<0.01$ level, CV: Variation coefficient, LSD: Least Significant Difference

\section{Crude Protein Content}

The crude protein content of alfalfa varieties are given in Table 4. There were no statistically significant differences among the crude protein contents. Crude protein contents ranged between $17.55 \%$ and $16.55 \%$.

Different crude protein ratios were reported by different studies conducted at different ecological areas. Yolcu et al. (2008), Awad and Bakri (2009), Katic et al. (2009), Kir (2010), Saruhan and Kusvuran (2011), Zeinab et al. (2013), Geleti et al. (2014), Inal (2015), Kavut and Avcioglu (2015) reported crude protein contents varying between 24.17-32.00\%, 19.99-26.96\%, 17.3-19.7\%, 22.21-23.31\%, 17.94-22.67\%, 18.5-23.0\%, 18.15-19.56 $\%, 18.38-20.45 \%, 19.83-20.11 \%$, respectively. Compared with these values it could be said that the alfalfa varieties studied in our research generally had lower crude protein contents. These differences could be due to cultivar and ecological differences. In the studies conducted with alfalfa varieties and lines under Erzurum ecological conditions (Sengul et al., 2003), as well as with alfalfa varieties in Ankara and Isparta (Yuksel et al., 2016), it was reported that the crude protein contents ranged between 15.95-18.21\% and 15.14-19.13\%, respectively. It could be said that the crude protein contents obtained from our research were within those ranges of change, and they were similar to the results (16.23-17.53\%) of the research conducted by Yilmaz and Albayrak (2016) under Isparta ecological conditions.

\section{Crude Protein Yield}

Crude protein yields are shown in Table 4. Cultivars $(\mathrm{P}<0.01)$ and years $(\mathrm{P}<0.05)$ varied significantly for the crude protein yields (Table 4$)$. The highest crude protein yield $\left(2827 \mathrm{~kg} \mathrm{ha}^{-1}\right)$ was obtained from cv. CW-3567 and the lowest crude protein yield $\left(1348 \mathrm{~kg} \mathrm{ha}^{-1}\right)$ was taken 
from Planet. Although crude protein content had nonsignificant varieties this could be due to differences in the hay yields depend on years and varieties. Many researchers have also reported that crude protein yield increased with dry matter yield (Akbari and Avcioglu, 1992; Kir and Soya, 2008).

Crude protein yields in our study were higher than 1219-2976 kg ha-1 given by Inal (2015). However Hansen and Krueger (1973), Sengul et al. (2003) and Yilmaz and Albayrak (2016) reported higher crude protein yields such as in the range of 2700-3250, 2464-3213 and 3174-3838 $\mathrm{kg} \mathrm{ha}^{-1}$, respectively.

\section{CONCLUSIONS}

Following the discussion of the results obtained in this it could be concluded that CW-3567 alfalfa variety was found to be suitable variety for fresh herbage, hay and crude protein yield. Besides, Van Native in terms of both fresh herbage and hay yields, and Kayseri variety could be considered in terms of hay yield adapted to the region. It could also be said that CW-3567, a foreign alfalfa variety, could be preferred for herbage (fresh and hay) yield and quality for Van ecological conditions. The dormancy degrees of alfalfa varieties used in our study ranged between 3-6. Although Planet had 3-4 dormancy degree, it gave the lowest fresh herbage and hay yields. Bilensoy- 80 having 6 dormancy degree gave lower yields than that the others having similar dormancy degrees. It is important to offer high yielded alfalfa varieties to the farmers for more production. In proposing new varieties dormancy degree could be used as an indicator. But, adaptation and stability studies are extremely important for the regions in where new varieties will be grown and both dormancy degree and adaptation trials will help researchers to choose a new cultivar for a special region. Although the study was carried out under limited ecological conditions of Van, the results may be applied to similar climatic zones and cultivar CW-3567 could be recommended to the similar locations.

\section{LITERATURE CITED}

Acikgoz, E. 2001. Forage Plants Textbook. Uludag University, Agricultural Faculty, Department of Field Crops, Bursa (in Turkish).

Akbari, N. 1992. Research on feed quality and agronomic characteristics of some alfalfa (Medicago sativa L.) varieties suitable for Aegean Region. PhD Thesis, Ege University, Faculty of Agriculture (Unpublished), Izmir.

Anonymous, 2017. Bugem Activities. T. C. Ministry of Food, Agriculture and Livestock, General Directorate of Plant Production, March 2017 (in Turkish)

Avcioglu, R. 1975. Researches on the effect of harvest season and height on yield and some other characteristics of alfalfa. $\mathrm{PhD}$ Thesis, Ege University Faculty of Agriculture (Unpublished), İzmir.

Awad, O.A. and E. Bakri. 2009. Effect of water quality and weeding on yield and quality of three alfalfa (Medicago sativa L.) cultivars. Australian Journal of Crop Science, 3(6): 315-321.

Aydin, I., Z. Acar and I. Erden. 1994. An investigation on hay and crude protein yield of some alfalfa varieties grown ecological conditions of Samsun. Turkey 1st Field Crops Congress, 25-29 April, Bornova/İzmir, p. 27-31 (in Turkish).

Bilensoy, C. 1985. Kayseri Alfalfa Improvement. T.C. Ministry of Agriculture, Forest and Livestock, General Directorate of Project and Application, Grassland, Meadow and Zootechnical Research Institute, National Research Projects on Grassland, Meadow and Forage Plants, Bovine and Ovine-Caprine Animal Breeding, Ankara, p. 171-187 (in Turkish).http://www.tarim.gov.tr/sgb/Belgeler/SagMenuVeri ler/BUGEM.pdf (Access date: 16.04.2017).

Cevheri, A.C. 1998. Investigations on the yield and other yield characteristics of 11 different alfalfa varieties under Bornova conditions. MSc Thesis. Ege University, Institute of Science, İzmir (in Turkish).

Demiroglu, G., H. Geren and R. Avcioglu. 2008. Adaptation of different alfalfa (Medicago sativa L.) genotypes under Aegean Region conditions. Journal of Agriculture Faculty of Ege University, 45 (1): 1-10 (in Turkish).

Demiroglu, G. and R. Avcioglu. 2010. A study on the performance of some new leguminous forage plants varieties in Mediterranean climatic conditions. Ege University, Journal of Agricultural Faculty, 47(2): 151-159 (in Turkish).

Eginlioglu, G., C.O. Sabanci, M. Bugdaycigil and H. Ozpinar. 1996. A study on the adaptation of some alfalfa (Medicago sativa L.) varieties to Menemen conditions. Turkey 3 rd Pasture and Forage Plants Congress, 17-19 June, Erzurum, p. 321-327 (in Turkish).

Geleti, D., M. Hailemariam, A. Mengistu and A. Tolera. 2014. Biomass yield potential and nutritive value of selected alfalfa (Medicago sativa L.) cultivars grown under tepid to cool sub-moist agro-ecology of Ethiopia. Journal of Agricultural Research and Development, 4(1): 7-14.

Inal, N. 2015. Determination of yield and quality characteristics of some alfalfa varieties under Kirsehir conditions. MSc Thesis, Ahi Evran University Institute of Science, Kirsehir (in Turkish),

Kacar, B. and A. Inal. 2008. Plant Analysis, Nobel Publication Distribution, ISBN 978-605-395-036-3, Ankara (in Turkish).

Kavut, Y.T., A.E. Celen, G. Demiroglu Topcu and B. Kir. 2014. An investigation on yield and some yield characteristics of different alfalfa genotypes grown in different locations. Journal of Agriculture Faculty of Ege University, 51 (1): 2329 (in Turkish).

Kavut, Y.T., and R. Avcioglu. 2015. Yield and quality performances of various alfalfa (Medicago sativa L.) cultivars in different Mediterranean environments. Turkish Journal of Field Crops, 20 (1): 65-71.

Kir, B. and H. Soya. 2008. The investigation on some yield and quality characteristics of some pasture type alfalfa cultivars. Journal of Agriculture Faculty of Ege University, 45 (1): 1119 (in Turkish).

Kir, H. 2010. A research on the determination of the performance of some alfalfa varieties under Tokat-Kazova conditions. MSc Thesis, Gaziosmanpasa University, Graduate School of Natural and Applied Sciences, Tokat (in Turkish).

Saruhan, V. and A. Kusvuran. 2011. Determination of yield performances of some lucerne cultivars and genotypes under the güneydoğu anadolu region conditions. Journal of Agriculture Faculty of Ege University, 48 (2): 133-140 (in Turkish).

Seker, H. 2003. Adaptation and yield trial of some new alfalfa cultivars to Erzurum ecological condition. Ataturk University, Journal of The Faculty of Agriculture, 34 (3): 217-221 (in Turkish).

Sengul, S. and L. Tahtacioglu. 1996. Determination of herbage (fresh and hay) and crude protein yields in various alfalfa 
varieties and lines in Erzurum ecological conditions. Turkey 3rd Pasture and Forage Plants Congress, 17-19 June, Erzurum, p. 608-614 (in Turkish).

Sengul, S., L. Tahtacioglu and A. Mermer. 2003. Determination of suitable alfalfa (Medicago sativa L.) cultivars and lines for Eastern Anatolian Region. Ataturk University, Journal of The Faculty of Agriculture, 34 (4): 321-325 (in Turkish).

Strbanovic, R., R. Stanisavljevic, L. Dukanovic, D. Postic, J. Markovic, V. Gavrilovic and N. Dolovac. 2017. Variability and correlation of yield and forage quality in alfalfa varieties of different origin. Journal of Agricultural Sciences, 23 (1): 128-137.

Tongel, M.O. and I. Ayan. 2010. Nutritional contents and yield performances of lucerne (Medicago sativa L.) cultivars in Southern Black Sea Shores. Journal of Animal and Veterinary Advances, 9(15): 2067-2073.

Yilmaz, M. and S. Albayrak. 2016. Determination of forage yield and quality of some alfalfa (Medicago sativa L.) cultivars under Isparta ecological conditions. Journal of Field Crops Central Research Institute, 25(1): $42-47$ (in Turkish).

Yolcu, H., M. Dasci, M. Tan and B. Comakli. 2008. Nutrient value of some lucerne cultivars based on chemical composition for livestock. Asian Journal of Chemistry, 20(5): 4110-4116

Steel, R.G.D. and J.H. Torrie. 1980. Principles and procedures of statistics: A Biometrical Approach. McGraw-Hill, New York.

Yuksel, O., S. Albayrak, M. Turk and C.S. Sevimay. 2016. Dry matter yields and some quality features of alfalfa (Medicago sativa L.) cultivars under two different locations of Turkey. Suleyman Demirel University, Journal of Natural and Applied Sciences, 20 (2): 155-160.

Zeinab, A.E.M., A.M. Sallam and N.A. Mohamed. 2013. Evaluating yield and quality of three alfalfa cultivars using laboratory and saline affected soil. Journal of American Science, 9(12): 5-14. 